\title{
Review : In Situ Gel Optalmik
}

\author{
Lutfiah Yusuf1, , Iyan Sopyan² \\ ${ }^{1}$ Program Studi Sarjana Farmasi, Fakultas Farmasi, Universitas Padjadjaran \\ ${ }^{2}$ Departemen Farmasetika dan Teknologi Farmasi, Fakultas Farmasi, Universitas Padjadjaran \\ *email: lutfiahyusuflulu@gmail.com \\ (Submit 9/8/2019, Diterima 12/8/2019)
}

\begin{abstract}
Abstrak
In situ gel optalmik merupakan sediaan gel untuk mata yang awalnya berupa larutan, namun ketika diteteskan pada mata akan berubah menjadi gel sehingga waktu kontak dengan mata akan lebih lama. Pembuatan in situ gel menggunakan matriks-matriks yang mengental apabila berada pada kondisi fisiologi tertentu seperti $\mathrm{pH}$, suhu dan konsentrasi ion. Sediaan optalmik konvensional seperti larutan, suspense dan salep memiliki kelemahan yaitu waktu kontak yang singkat dengan kornea mata serta tidak nyaman digunakan. In situ gel dibuat untuk mengatasi kelemahan atau kekurangan yang terkait dengan drug delivery system (Sistem Penghantaran Obat) dan memiliki potensi yang besar untuk dijadikan sebagai ocullar therapy karena memiliki waktu kontak yang lama dengan kornea mata.
\end{abstract}

Kata Kunci : In situ gel, Optalmik, Sistem penghantaran obat.

\section{Outline}

- Pendahuluan

- Metode

- Pembahasan

- Natrium Alginat dan Hidroksi Propil Metil Selulosa (HPMC)

- Pektin dan Natrium Alginat

- Pluronic F-127, Gellan-gum, dan Karbopol

- Karbopol dan HPMC

- Karbopol 934 dan Pluronic F-127

- Poloxamer 188\&407 dan HPMC

- Natrium Alginat, Noveon AA-1 polycarbophil dan HPMC E50LV

- Kesimpulan

- Daftar Pustaka

\section{Pendahuluan}

Gel adalah sediaan yang transparan karena mengandung banyak air serta mempunyai penghantaran obat yang lebih baik dibandingkan dengan salep (Sudjono et al., 2012; Verma et al., 2013). 
Karena sediaan optalmik konvensional memilik banyak kekurangan maka In situ gel optalmik merupakan perkembangan dari sediaan gel yang dibuat dengan tujuan agar efektifitas obat meningkat, mengurangi eliminasi obat yang cepat, meningkatkan bioavailabilitas dan mengurangi iritasi pada mata. (Chitra et al, 2018). Hal-hal yang harus diperhatikan untuk sediaan in situ gel adalah sebagai berikut ; Gelasi (Sol-Gel fase transisi), $\mathrm{pH}$ optimal, steril, stabil, jernih, pelepasan obat diperpanjang, sifat viskositas, permeabilitas terhadap kornea mata, kandungan obat, isotonisitas, reprodusibilitas dan kelengketan. (Lin et al, 2009).

\section{Metode}

Metode pengumpulan data untuk penulisan review artikel ini dilakukan dengan studi literatur. Adapun studi literatur dilakukan dengan menelaah artikel dan jurnal ilmiah yang dipublikasi secara nasional maupun internasional dalam 10 tahun terakhir, yaitu antara tahun 2009-2019, terkait in situ gel optalmik.

\section{Pembahasan}

Secara umum evaluasi sediaan optalmik terdiri dari pengujian $\mathrm{pH}$, Kejernihan, Sterilitas, dan Pirogenitas. Uji pH dilakukan dengan $\mathrm{pH}$ meter atau kertas indicator universal, $\mathrm{pH}$ sediaan optalmik harus disesuaikan dengan $\mathrm{pH}$ mata. Uji kejernihan dilakukan secara visual dengan latar belakang hitam dan putih serta pencahayaan yang baik, uji kejernihan harus terbebas dari partikel-partikel kecil. Uji Sterilitas dilakukan dengan menggunakan media pertumbuhan bakteri dan jamur lalu media tersebut diinkubasi, setelah diinkubasi dilihat apakah ada pertumbuhan mikroorganisme pada media tersebut. Uji pirogenitas biasanya menggunakan kelinci sebagai hewan percobaan, sediaan uji diteteskan atau diaplikasikan pada mata kelinci dan diamati setelah beberapa hari pemberian sediaan uji.

\section{Natrium Alginat dan Hidroksi Propil Metil Selulosa (HPMC)}

Salah satu polimer In situ gel yang biasa digunakan adalah Natrium Alginat dan HPMC. Natrium Alginat merupakan polimer mukoadhesif pembentuk gel ophthalmic yang akan menjadi gel dengan adanya kation divalen (ion kalsium) yang ada dalam cairan lachrymal pada mata $(\mathrm{pH} 7,4)$ dan digunakan sebagai zat pembentuk gel. HPMC merupakan polimer mukoadhesive yang digunakan sebagai penambah viskositas. Natrium alginate sebagai polimer utama dan HPMC sebagai co-polimer. Pembuatan in situ gel dilakukan dengan cara melarutkan Natrium alginate dan HPMC dalam air dengan magnetic stirer lalu ditambahkan larutan buffer dan $\mathrm{HCl}$ untuk membuat $\mathrm{pH}$ menjadi 6,5. Ada 6 formula yang akan diuji dengan perbedaan massa polimer-polimer yang digunakan. Natrium Alginat yang digunakan adalah 0,5 gram, 1 gram dan 1,5 gram sedangan HPMC K4M 0.5 gram dan HPMC E50LV 2,5 gram. Evaluasi pelepasan in vitro menunjukkan bahwa rentang kadar obat dari semua formulasi adalah $78,71 \%$ 93,86\%. Uji Iritasi dilakukan pada kelinci albino dan tidak ditemukan adanya kemerahan, kedipan mata yang berlebihan, mata berair, serta tidak adanya gejala klinik pada kornea, iris, atau konjungtiva. Uji stabilitas juga dilakukan selama satu bulan dan dianalisis tiap satu minggu, hasilnya adalah tidak ada perubahan secara visual dan $\mathrm{pH}$. 


\section{Pektin dan Natrium Alginat}

Menurut Neeraj Mittal dan Gurpreet Kaur, 2014 dibuat dua formulasi in situ gel dengan menggunakan polimer yang berbeda yaitu Pektin dengan Natrium Alginat dan Pektin saja. Kombinasi Pektin dengan Natrium Alginat menghasilkan karakteristik pelepasan yang baik. In situ gel dibuat dengan cara melarutkan pectin dan natrium alginat dalam larutan buffer $\mathrm{pH} 7.4$ lalu ditambahkan $\mathrm{NaCl}$ agar larutan isotonic dan disterilkan dalam autoklaf $121^{\circ} \mathrm{C}$ dengan tekanan $15 \mathrm{~Pa}$ selama 20 menit kemudian disimpan dalam kulkas dengan suhu $4-8^{\circ} \mathrm{C}$. Sampel dievaluasi secara in vivo menggunakan kelinci, hasilnya membuktikan bahwa in situ gel dengan polimer tersebut dapat menurunkan ekanan intraocular (IOP) pada mata kelinci dan formulasi baru ini juga memiliki kemampuan untuk memperpanjang pelepasan obat karena waktu kontak dengan kornea lebih lama dibandingkan dengan formulasi obat tetes mata konvensional.

Pluronic F-127, Gellan-gum, dan Karbopol

Menurut Gupta et al 2018, terdapat 13 formula yang akan diuji dengan konsentrasi Pluronic F-127, Gellan-gum, dan Karbopol yang berbeda-beda. Lalu dilakukan beberapa evaluasi terhadap 13 formula tersebut, diantaranya uji sterilitas dengan metode Kirby-Bauer Disk Diffusion, uji iritasi mata secara in vivo, Uji MRT (Mean Release Time), uji kejernihan, $\mathrm{pH}$, uji rheology dan suhu gelasi. 13 formula tersebut memiliki tampilan yang transparan dan tidak kasar.

Uji rheology dilakukan untuk mengetahuin nilai viskositas, Nilai viskositas dari formula 1 sampai 13 adalah sebagai berikut 295, 250, 485, 255, 210, 225, 460, 475, 265, 307, 235, 280 dan $460 \mathrm{mPa}$.S. Uji MRT dilakukan untuk melihat waktu pelepasan obat, waktu dari formulasi 1 sampai 13 adalah sebagai berikut 2.9, 2.8, 3.1, 2.7, 2.6, 2.6, 3.1, 2.9, 2.9, 3.1, 2.8, 2.9 dan 2.9 jam. Hasil dari suhu gelasi dari formula 1 sampai 13 adalah sebagai berikut 34, 27, 17, 36, 29, 36, 24, 33, 20, 18, 20, 27 dan 26.

Setelah evaluasi tersebut didapatkan formulasi yang optimum adalah sebagai berikut; Plurionik $(11,50 \%$ b / v), gellan-gum $(0,32 \%$ b / v), karbopol $(0,3 \%$ b / v) kemudian dilakukan uji sterilitas dengan metode Kirby-Bauer disk diffusion menggunakan cawan petri dengan diameter $10 \mathrm{~mm}$. Media agar dan gel dimasukkan ke dalam cawan petri secara steril di laminar air flow (LAF) lalu diinkubasi.

Kultur mikroba yang digunakan adalah Pseudomonas aueroginosa dan staphylococcus aureus lalu diinokulasi menggunakan cotton swabs yang steril. Cawan petri diinkubasi pada suhu $37 \pm 0.5^{\circ} \mathrm{C}$ selama 24 jam dan menunjukkan hasil bahwa tidak ada mikroba yang tumbuh pada cawan petri tersebut.

Selanjutnya dilakukan uji iritasi menggunakan mata kelinci, 4 hari sebelum pengujian kelinci diaklimasi. $0,1 \mathrm{ml}$ sediaan uji diteteskan 2 kali sehari pada mata kelinci selama 14 hari, hasilnya menunjukkan bahwa tidak terjadi iritasi pada mata kelinci. 
Menurut Aliggati et al 2018 karbopol yang digunakan yaitu karbopol 934, 940 dan 971 dengan konsentrasi $0.1 \% \mathrm{w} / \mathrm{v}, 0.3 \% \mathrm{w} / \mathrm{v}$, dan $0.5 \% \mathrm{w} / \mathrm{v}$ serta HPMC yang digunakan yaitu HPMC E15, K4M, dan K100 dengan konsentrasi 1\% w/v dan 1.5\% w/v yang dilarutkan dalam air dengan pengadukan hingga homogen lalu didiamkan selama semalam.

Formula yang optimum menggunakan karbopol 971 dengan konsentrasi $0,3 \% \mathrm{w} / \mathrm{v}$ sebagai gelling agent dan dikombinasikan dengan HPMC E15 konsentrasi 1\% w/v sebagai penambah viskositas menghasilkan gel yang jernih, memiliki kapasitas in situ gelling yang baik, steril dan pelepasan obat lebih dari 8 jam. Formulasi ini juga menunjukkan "sustained drug release with prolonged" yang meningkatkan efektifitas obat.

Formula tersebut menghasilkan gel yang jernih pada uji kejernihan dengan $\mathrm{pH} 7,4$ dan kandungan zat aktif $99.5 \pm 0.5 \%$. Evaluasi viskositas dilakukan dengan berbagai rpm yang berbeda yaitu $10,20,30,50,100$ dan pada 2 suhu yaitu 25 derajat Celcius (Sebelum gelasi) dan 37 derajat Celcius (Setelah gelasi). Uji sterilitas dilakukan dengan masa inkubasi selama 7 hari dan tidak ditemukan adanya pertumbuhan bakteri pada media tersebut.

\section{Karbopol 934 dan Pluronic F-127}

Menurut A. E. s. F. Abou el Ela, M.M.E. Khatib 2014 Pluronic F127 dibuat dengan dua konsentrasi yaitu $25 \%$ dan $30 \%$ sedangkan konsentrasi karbopol sebesar $1 \%$ dan $2 \%$. Semua formula dilakukan evaluasi diantaranya adalah uji kejernihan, pengukuran $\mathrm{pH}$, pelepeasan secara in vitro dan in vivo, uji rheology dan Differential Scanning Calorimetry (DSC). Semua formula menunjukkan hasil visual yang jernih dengan rentang $\mathrm{pH}$ 6,84 - 6,92 yang menunjukkan bahwa $\mathrm{pH}$ tersebut dapat diterima untuk menghindari iritasi pada mata ketika diaplikasikan. Uji kompatibilitas dilakukan dengan menggunakan DSC dan memberikan hasil bahwa tidak ada perubahan yang signifikan pada thaw melting point setelah pencampuran zat aktif dengan polimer-polimer yang digunakan. Thaw melting point yang didapat yaitu 119,$46 ; 111,1$ dan 114,88 . Hasil ini menjukkan bahwa tidak ada interaksi antara zat aktif dengan polimer-polimer. Hasil dari uji rheology menunjukkan bahwa semua formulasi memiliki aliran non Newtonian pseudoplastic. Uji in vivo dilakukan pada mata kelinci dengan melihat tekanan Intraokular (IOP) yang menunjukkan bahwa pelepasan obat diperpanjang lebih dari 5 jam yang akan meningkatkan efektivitas obat.

\section{Poloxamer 188\&407 dan HPMC}

Poloxamer 407 sebagai gelling agent dikombinasikan dengan HPMC K4M sebagai penambah viskositas. Optimasi formula poloxamer 407 dengan konsentrasi 16,25\% $\mathrm{w} / \mathrm{w}$ dan HPMC K4M dengan konsentrasi $0.6 \% \mathrm{w} / \mathrm{w}$ menghasilkan pelepasan obat secara in vitro diperpanjang yaitu lebih dari 8 jam. 
Poloxamer 407 memberikan warna yang lebih transparan dibandingkan dengan Poloxamer 188. Ketika konsentrasi HPMC meningkat maka daya lekat pada mata juga meningkat. Pembuatan in situ gel dilakukan dengan melarutkan Poloxamer 407 dalam $50 \mathrm{ml}$ ultrapure water (UPW). Larutan disimpan dalam kulkas selama 24 jam untuk memastikan bahwa polimer telah larut sempurna dan menghasilkan larutan yang jernih. Polimer HPMC K4M dilarutkan dalam $40 \mathrm{ml}$ UPW lalu dipanaskan hingga 70 oC dan dihomogenkan dengan magnetic stirrer hingga terbentuk larutan yang jernih. Kedua larutan polimer tersebut ditambahkan $0,5 \mathrm{M} \mathrm{NaOH}$ agar $\mathrm{pH}$ nya menjadi 6,5 - 7,4. Ditambahkan $\mathrm{NaCl} 0,2$ untuk membuat larutan menjadi osmolaritas dengan rentang 290 - 310 mOsm kg-1.

Dinatrium EDTA $0.05 \%$ dan Benzalkonium chloride $0.001 \%$ juga ditambahkan ke dalam formulasi dan kemudian disterilisasi dengan autoclave dengan suhu $1210 \mathrm{C}$ dan tekanan $15 \mathrm{PSI}$ selama 15 menit. Evaluasi menggunakan Fourier transform infrared spectroscopy (FTIR) menunjukkan bahwa tidak ada interaksi kimia antara zat aktif dengan poloxamer 407.

Viskositas gel diukur sebanyak dua kali yaitu sebelum dan sesudah gelasi menggunakan viscometer Brookfield dengan kecepatan 10, 20, 30, 50, 60, 75, 100, 120, 150 dan 200 rpm menggunakan spindle LVDV Nomor 61, 62, 63 dan 64 dengan suhu 200 oC Hasil dari uji viskositas adalah semua formulasi memiliki rentang 10-150 cps dan menunjukkan aliran Non-Newtonian pseudoplastic.

Uji sterilitas dilakukan pada bakteri aerobic, anaerobic dan jamur dengan menggunakan medium thioglycolate dan soybean casein digest. Bacillus subtilis, Bacterio desvulgatus dan Candida albicans merupakan mikroorganisme yang digunakan pada uji sterilitas. Kemudia medium diinkubasi pada suhu 350C dan 20-250C dan dianalisis selama 21 hari. Hasilnya menunjukkan bahwa tidak ditemukan adanya bakteri. Uji Iritasi secara in vivo dilakukan pada 8 group kelinci albino. 20 microliters sediaan in situ gel diteteskan pada mata kelinci sebelah kanan sedangkan mata sebelah kiri dijadikan sebagai control tanpa sediaan uji. Mata kelinci diamati pada 0, 5, 10, 30 menit, 1, 6, 12, 24, 48 dan 72 jam. Hasil dari uji iritasi secara in vivo tidak mengakibatkan iritasi pada mata kelinci dan formula in situ gel tersebut aman untuk dijadikan sebagai ocular therapy.

\section{Natrium Alginat, Noveon AA-1 polycarbophil dan HPMC E50LV}

Natrium Alginat digunakan sebagai gelling agent, , Noveon AA-1 polycarbophil dan HPMC E50LV sebagai penambah viskositas. Menurut Prasanth et al 2017, ada 8 formulasi in situ gel yang akan diuji dan 2 formulasi yang menghasilkan efektivitas paling baik yaitu HPMC E50LV 0,5\% (w/v) dan Noveon AA-1 polycarbophil 0,5\% (w/v) serta formulasi yang kedua yaitu HPMC E50LV 0,5\% (w/v) dan Natrium Alginat 0,5\% $(\mathrm{w} / \mathrm{v})$. Rentang $\mathrm{pH}$ yang digunakan untuk formulasi yaitu 6,5-7,0. Pada formulasi ini digunakan Benzalkonium Klorida sebagai preservative. Evaluasi kandungan zat aktif bervariasi antara $96.84 \pm 0.396 \%$ dan $99.65 \pm 0.489 \%$ yang menandakan bahwa keseragaman distribusi obat ada di semua formulasi. 
Uji rheology memberikan hasil yang berbanding terbalik, ketika viskositas dari semua formulasi berkurang maka shear rate meningkat, yang menandakan bahwa aliran nya bersifat pseudoplastic. Jika viskositas terlalu tinggi akan mengakibatkan iritasi mata dan jika terlalu rendah akan meningkatkan drainase. Maka dari itu, formulasi in situ gel harus memiliki viskositas yang optimum untuk mempermudah penggunaannya pada mata dalam bentuk cairan yang akan bertransisi menjadi solid-to-gel. Uji strilitas dilakukan dengan menginkubasi selama 14 hari dengan suhu 30-35 0C pada media Thioglycolat dan 20-250C pada media Soybean Casein Digest. Setelah inkubasi hasilnya menunjukkan bahwa formula 1 dan formula 2 baik sebagai antimikroba pada bakteri Staphylococcus aureus dan Pseudomonas aeruginosa. Pada uji iritasi mata menunjukkan bahwa formula tersebut tidak mengiritasi dan tidak menunjukkan tanda kerusakan pada mata.

\section{Kesimpulan}

In situ gel optalmik merupakan sediaan gel untuk mata yang awalnya berupa larutan, namun ketika diteteskan pada mata akan berubah menjadi gel sehingga waktu kontak dengan mata akan lebih lama dan meningkatkan efektivitas obat. Pembuatan in situ gel dapat menggunakan berbagai macam polimer diantaranya Natrium Alginat, Hidroksi Propil Metil Selulosa (HPMC), Pektin, Pluronic F-127, Gellan-gum, Karbopol, Poloxamer 188, Poloxamer 407, dan Noveon AA-1 polycarbophil yang telah diuji secara in vitro maupun in vivo.

\section{Daftar Pustaka}

Abou el Ela dan M.M.E. Khatib 2014. Formulation and evaluation of new long acting metoprolol tartrate ophthalmic gels. Saudi Pharmaceutical Journal Volume 22 (555563). Saudi Arabia

Aligeti et al. 2018. Formulation and Evaluation of Flurbiprofen Ocular In-Situ Gel. IJPSR Volume 9(5): 1851-1856. India

Bain et al. 2009. In Situ Fast Gelling Formulation of Methyl Cellulose for In Vitro Ophthalmic Controlled Delivery of Ketorolac Tromethamine. Journal of Applied Polymer Science Volume 113 (1241-1246). India.

Bazzaz et al. 2018. Ophthalmic In-Situ Sustained Gel of Ciprofloxacin, Preparation and Evaluation Study. Intenational Journal Applied Pharmaceutical Volume 10(4) 153-161. Iraq

Bhushan s bhoyar dan Arun t patil. 2015. Formulation and Evaluation of Ophthalmic Gel Based on Drug-polymerpolymer Ternary Interaction. Asian Journal of Pharmaceutical and Clinical Research Volume 8(3) .India.

Chitra gupta, Vijay juyal, dan Upendra nagaich. 2018. Formulation and Optimization of Thermosensitive in-situ Gel of Moxifloxacin Hydrochloride For Ocular Drug Delivery. International Journal of Applied Pharmaceutics Volume 10(3). India. 
Dasankoppa et al. 2017. Design, formulation, and evaluation of in situ gelling ophthalmic drug delivery system comprising anionic and nonionic polymers. Indian Journal of Health Sciences and Biomedical Research Volume 10(3). India.

Jain et al. 2016. Newer Trends in In Situ Gelling Systems for Controlled Ocular Drug Delivery. Journal of Analytical \& Pharmaceutical Research Volume 2(3). India

J, Song et al. 2013. Preparation and evaluation of sinomenine hydrochloride in situ gel for uveitis treatment.Internationallmmunopha rmacology Volume 17 (99-107). China

Lavanya et al. 2014. Formulation and Evaluation of Oculat Niosomal in situ gels of Linezolid. IJPSR. Volume 5(4): 1367-1375. India.

Lin, Zhuanga et al. 2009. Liposome coated with low molecular weight chitosan and its potensial use in ocular drug delivery. International Journal of Pharmaceutics Volume $379(131-1380$

Liu et al. 2010. In Situ Gelling Gelrite/Alginate Formulations as Vehicles for Ophthalmic Drug Delivery. AAPS Pharmacetutical Science Technology Volume 11(2). China.

Mandal et al. 2012. Formulation and evaluation of an in situ gel-forming ophthalmic formulation of moxifloxacin hydrochloride. International Journal of Pharmaceutical Investigation Vol 2(2). India.

Neeraj Mittal dan Gurpreet Kaur. 2014. In Situ Gelling Ophthalmic Drug Delivery System: Formulation and Evaluation. Journal Applied Polymer Science. India.

Prasanth et al. 2017. Formulation and Evaluation of In Situ Ocular Gel of Levofloxacin. Journal of Drug Delivery \& Therapeutics Volume 7(5):68-73. Saudi Arabia.

Ramanjit, Saini et al. 2015. In Situ Gels- a New Trends in Ophthalmic Drug Delivery Systems. IJPSR Vol 6(5). India

$\mathrm{R}$, Asasutjarit et al. 2011.Optimization and evaluation of thermoresponsive diclofenac sodium ophthalmic in situ gels. International Journal of Pharmaceutics 411: 128-135

Reeshanteni Balasingam, Abdullah Khan, dan Rajermani Thinakaran.2017. Formulation of In Situ Gelling System for Ophthalmic Delivery of Erythromycin. International Journal of Students Research In Technology \& Management Volume 5(3) 2321-2543. India.

S.B. Makwana et al. 2016. Development and characterization of in-situ gel for ophthalmic formulation containing ciprofloxacin hydrochloride. Results in Pharma Sciences Volume 6 (16). India. 
Sudjono, T. A., Honniasih, M., \& Pratimasari, Y. R. 2012. Pengaruh Konsentrasi Gelling agent Karbomer 934 dan HPMC Pada Formulasi Gel Lendir Bekicot (Achatina Fulica) Terhadap Kecepatan Penyembuhan Luka Bakar Pada Punggung Kelinci. Pharmacon Pharmaceutical Journal of Indonesia, 13(1), 6-11.

Verma, A., Singh, S., Kaur, R., and Jain, U. K. 2013). Formulation and Evaluation of Clobetasol Propionate Gel. Asian Journal of Pharmaceutical and Clinical Research, $6(5)$. 